\title{
Lignocellulolytic Enzyme Production from Wood Rot Fungi Collected in Chiapas, Mexico, and Their Growth on Lignocellulosic Material
}

\author{
Lina Dafne Sánchez-Corzo ${ }^{1}$, Peggy Elizabeth Álvarez-Gutiérrez ${ }^{1}{ }^{\circledR}$, Rocío Meza-Gordillo ${ }^{1}(\mathbb{D}$, \\ Juan José Villalobos-Maldonado ${ }^{1}$, Sofía Enciso-Pinto ${ }^{2}$ and Samuel Enciso-Sáenz ${ }^{1, *}$ \\ 1 National Technological of Mexico-Technological Institute of Tuxtla Gutiérrez, Carretera Panamericana \\ km. 1080, Boulevares, C.P., Tuxtla Gutiérrez 29050, Mexico; D18270772@tuxtla.tecnm.mx (L.D.S.-C.); \\ peggy.ag@tuxtla.tecnm.mx (P.E.Á.-G.); rocio.mg@tuxtla.tecnm.mx (R.M.-G.); \\ juan.vm@tuxtla.tecnm.mx (J.J.V.-M.) \\ 2 Institute of Biomedical Research, National Autonomous University of Mexico, \\ Circuito, Mario de La Cueva s/n, C.U., Coyoacán, México City 04510, Mexico; sofienciso@hotmail.com \\ * Correspondence: samuel.es@tuxtla.tecnm.mx; Tel.: +52-96-150461 (ext. 304)
}

Citation: Sánchez-Corzo, L.D. Álvarez-Gutiérrez, P.E.; Meza-Gordillo, R.;

Villalobos-Maldonado, J.J.; Enciso-Pinto, S.; Enciso-Sáenz, S. Lignocellulolytic Enzyme Production from Wood Rot Fungi Collected in Chiapas, Mexico, and Their Growth on Lignocellulosic Material. J. Fungi 2021, 7, 450. https://doi.org/ $10.3390 /$ jof7060450

Academic Editor: Craig Faulds

Received: 28 April 2021

Accepted: 2 June 2021

Published: 5 June 2021

Publisher's Note: MDPI stays neutral with regard to jurisdictional claims in published maps and institutional affiliations.

Copyright: (c) 2021 by the authors. Licensee MDPI, Basel, Switzerland. This article is an open access article distributed under the terms and conditions of the Creative Commons Attribution (CC BY) license (https:// creativecommons.org/licenses/by/ $4.0 /)$.

\begin{abstract}
Wood-decay fungi are characterized by ligninolytic and hydrolytic enzymes that act through non-specific oxidation and hydrolytic reactions. The objective of this work was to evaluate the production of lignocellulolytic enzymes from collected fungi and to analyze their growth on lignocellulosic material. The study considered 18 species isolated from collections made in the state of Chiapas, Mexico, identified by taxonomic and molecular techniques, finding 11 different families. The growth rates of each isolate were obtained in culture media with African palm husk (PH), coffee husk $(\mathrm{CH})$, pine sawdust (PS), and glucose as control, measuring daily growth with images analyzed in ImageJ software, finding the highest growth rate in the $\mathrm{CH}$ medium. The potency index (PI) of cellulase, xylanase, and manganese peroxidase $(\mathrm{MnP})$ activities was determined, as well as the quantification of lignin peroxidase (LiP), with the strains Phlebiopsis flavidoalba TecNM-ITTG L20-19 and Phanerochaete sordida TecNM-ITTG L32-1-19 being the ones with the highest PI of hydrolase activities with 2.01 and 1.83 cellulase PI and 1.95 and 2.24 xylanase PI, respectively, while Phlebiopsis flavidoalba TecNM-ITTG L20-19 and Trametes sanguinea TecNM-ITTG L14-19 with 7115 U/L LiP activity had the highest oxidase activities, indicating their ability to oxidize complex molecules such as lignin.
\end{abstract}

Keywords: fungi; ligninolytic enzymes; cellulase; xylanase; lignocellulosic biomass; manganese peroxidase; lignin peroxidase

\section{Introduction}

Lignocellulolytic enzymes capable of degrading hardwoods play an important ecological role as degraders of lignocellulosic biomass, in addition to having multiple applications in the textile, pharmaceutical, paper, food, cosmetic, environmental, biotechnological, detergent, and biofuel industries [1,2].

The importance of lignocellulolytic enzymes and the diversity of fungal species that produce them focus interest on the evaluation of their applications using agroindustrial waste that is disposed of without treatment as inducers for enzyme production.

Currently, the development of new technologies has been proposed to remove these pollutants from the environment. For this reason, numerous biological techniques involving organisms such as fungi have been developed for the removal of organic pollutants.

Among the fungi of interest are lignocellulolytic fungi, which are those that use lignocellulosic material as a source of carbon and energy. It is important to note that lignocellulosic materials are mainly composed of cellulose, hemicellulose, and lignin [1]; 
the latter being of great interest since it is a complex compound that has multiple aromatic rings in its structure. Fungi have developed a collection of extracellular oxidative enzymes to degrade lignin. They employ different types of peroxidases, including lignin peroxidase $(\mathrm{LiP})$, manganese peroxidase $(\mathrm{MnP})$, and versatile peroxidases $(\mathrm{VP})$. While some of these enzymes are capable of degrading lignin or lignin fragments, peroxidases also degrade lignin through oxidative mediators, small oxidizing agents that can penetrate the branched lignin polymer to trigger depolymerization. Lignocellulolytic fungi degrade cellulose, hemicellulose, lignin (main wood compounds), lignocellulosic residues, and a variety of environmental pollutants to use them as a source of carbon and energy, due to their secretion of extracellular hydrolase and oxidase enzymes such as cellulase, xylanase, manganese peroxidase, laccase and lignin peroxidase [3,4].

The fungi that cause white wood rot are characterized by possessing a group of enzymes capable of degrading wood lignin known as ligninases or ligninolytic enzymes. Lignin is what gives wood its characteristic brown color, which when degraded by these fungi is enriched in cellulose whose color is white, hence the name of this type of rot. There are two groups of white-rot fungi: the simultaneous white-rot fungi consume lignin and carbohydrates rather parallelly and to a similar extent, whereas the selective white-rot species at least in the beginning prefer the lignin [5]. Within this group of ligninolytic enzymes, there are hydrolases, oxidases, and peroxidases whose function is to begin the consumption of lignin through strong oxidations. It is important to mention that the reactions carried out by these enzymes are nonspecific since they oxidize lignin and a variety of aromatic compounds [6-8].

Therefore, this work aims to evaluate the production of lignocellulolytic enzymes from eighteen isolates of lignocellulolytic fungi collected in Chiapas, Mexico, and to analyze their growth on lignocellulosic material, providing perspectives for research regarding the degradation of environmental pollutants and agroindustrial residues as well as their biotechnological applications in obtaining by-products with added value.

\section{Materials and Methods}

\subsection{Organisms}

Specimens of white and brown wood rot fungi were collected from three different sites in the state of Chiapas, Mexico: (1) San José Educational Park (SJEP) $\left(16^{\circ} 43^{\prime} 26.54^{\prime \prime} \mathrm{N}\right.$ and $\left.92^{\circ} 41^{\prime} 55.55^{\prime \prime} \mathrm{W}\right)$, located at an altitude between 2350 and $2380 \mathrm{~m}$ above sea level (masl), with a predominantly humid temperate climate with summer rains, mean annual temperature of $25.1^{\circ} \mathrm{C}$, annual precipitation of approximately $1276 \mathrm{~mm}$, and vegetation consisting of pine-oak forests; (2) Laguna Verde Ecotourism Park (LVEP) (1 $7^{\circ} 07^{\prime} 56.37^{\prime \prime} \mathrm{N}$ and $93^{\circ} 09^{\prime} 48.77^{\prime \prime} \mathrm{W}$ ), with an altitude between 1599 and $1631 \mathrm{~m}$ above sea level, semiwarm sub-humid climate with summer rains, annual rainfall of $1800 \mathrm{~mm}$, average annual temperature of $27.3{ }^{\circ} \mathrm{C}$ and medium rainforest vegetation; (3) Facilities of the National Technological of Mexico-Technological Institute of Tuxtla Gutiérrez (TecNM-ITTG by its Spanish acronym) $\left(16^{\circ} 45^{\prime} 27.63^{\prime \prime} \mathrm{N}\right.$ and $\left.93^{\circ} 10^{\prime} 21.75^{\prime \prime} \mathrm{W}\right)$, at 577 masl, warm sub-humid climate with summer rains, mean annual temperature of $33.2^{\circ} \mathrm{C}$, average annual rainfall of $900 \mathrm{~mm}$ and predominant vegetation of low deciduous forest [9-12]. For isolation and propagation, the collected macromycetes were disinfected, washing them with water to remove the residues of the substrate, and subsequently three washes were performed: sodium hypochlorite (5\%) for $1 \mathrm{~min}$, distilled water (to remove chlorine residues) for $1 \mathrm{~min}$ and ethanol ( $70 \%)$ for $1 \mathrm{~min}$, at once, in the laminar flow bell, the macromycetes were rinsed with sterile distilled water. With a sterile scalpel, a vertical cut was made in the carpophore, and with a sterile dissection clamp the tissue was recovered and inoculated in solid medium of potato-dextrose agar (PDA) to obtain mycelium, at a temperature of $28 \pm 1{ }^{\circ} \mathrm{C}$. Each sample was assigned a key for identification. 


\subsection{Identification}

Specimens were taxonomically identified by macroscopic and microscopic characteristics and dichotomous keys [13-17].

To carry out molecular identification, total genomic DNA was extracted from fungal isolates with a miniprep kit (ZYMO RESEARCH, California, USA), according to manufacturer's instructions. Genomic DNA was amplified using the fungal specific primers ITS 4 (5-TCCTCCGCTTCTTATTGATATATGC-3) and ITS 5 (5-CTTGGTCATTTAGAGGAAGTAA3) [18]. Amplification was performed on a thermal cycler (SensoQuest, Göttingen, Germany) programmed as follows: $92{ }^{\circ} \mathrm{C}$ for $5 \mathrm{~min}, 35$ cycles at $92{ }^{\circ} \mathrm{C}$ for $30 \mathrm{~s}, 52{ }^{\circ} \mathrm{C}$ for $30 \mathrm{~s}, 72{ }^{\circ} \mathrm{C}$ for $45 \mathrm{~s}$, followed by a 5 min extension step at $72{ }^{\circ} \mathrm{C}$. PCR products were electrophoresed at $85 \mathrm{~V}$ on $1 \%$ agarose gels and the resulting bands were observed on a UV transilluminator (BIO-RAD, Hercules, CA, USA). The amplifications were sequenced at Macrogen Laboratories (Korea). Once the sequences were obtained, they were analyzed and nucleotide sequence similarity search was performed in GenBank using the Basic Local Alignment Search Tool (BLAST) [19], from the National Center for Biotechnology Information (NCBI).

\subsection{Isolates Growth in Solid Culture Media}

For the evaluation of fungal mycelial growth, a modified mineral salt solution was added to all the culture media [20], containing (g/L): $\mathrm{NaNO}_{3}(18), \mathrm{KH}_{2} \mathrm{PO}_{4}(1.3), \mathrm{MgSO}_{4} \cdot 7 \mathrm{H}_{2} \mathrm{O}(0.38)$, $\mathrm{CaSO}_{4} \cdot 2 \mathrm{H}_{2} \mathrm{O}(0.25), \mathrm{CaCl}_{2}(0.055), \mathrm{FeSO}_{4} \cdot 7 \mathrm{H}_{2} \mathrm{O}(0.015), \mathrm{MnSO}_{4} \cdot \mathrm{H}_{2} \mathrm{O}(0.012), \mathrm{ZnSO}_{4} \cdot 7 \mathrm{H}_{2} \mathrm{O}$ (0.013), $\mathrm{CuSO}_{4} \cdot 7 \mathrm{H}_{2} \mathrm{O}(0.0023), \mathrm{CoCl}_{2} \cdot 6 \mathrm{H}_{2} \mathrm{O}(0.0015)$ and $\mathrm{H}_{3} \mathrm{BO}_{3}(0.0015)$ and phosphate solution $\left(\mathrm{K}_{2} \mathrm{HPO}_{4} 45.6 \mathrm{~g} / \mathrm{L}\right.$ and $\left.\mathrm{KH}_{2} \mathrm{PO}_{4} 27.2 \mathrm{~g} / \mathrm{L}\right)$, in addition to a carbon source.

Three agroindustrial substrates were selected as a carbon source: African palm husk $(\mathrm{PH})$ from Elaeis guineensis (belonging to the residue in the oil process of the company OLEOSUR S. A. de C.V. located in the municipality of Acapetahua, Chiapas, Mexico), coffee husk $(\mathrm{CH})$ from Coffea arabica (from waste from the company PRANA, located in the municipality of Tuxtla Gutiérrez, Chiapas, Mexico) and pine sawdust (PS) from Pinus spp. The substrates were ground and sieved in a No. 100 mesh, particle size $0.149 \mathrm{~mm}$. For the medium, $2 \%$ agar and 5\% agroindustrial substrate were added as carbon source and the isolated fungi were inoculated and incubated at a temperature of $28 \pm 1{ }^{\circ} \mathrm{C}$ [21].

The control medium was prepared with $2 \%$ agar and $10 \mathrm{~g} / \mathrm{L}$ of glucose (control) as a carbon source, and this medium was inoculated with the isolated fungi and incubated at a temperature of $28 \pm 1{ }^{\circ} \mathrm{C}$.

The mycelial growth rate $(\mathrm{mm} / \mathrm{d})$ was measured every $24 \mathrm{~h}$ until the end of the exponential growth phase of each strain using images analyzed with ImageJ software (Image Processing and Analysis in Java, National Institutes of Health, Bethesda, MD, USA), using a vernier as a scale [22].

\subsection{Cellulase Activity}

For semi-quantitative test of cellulase activity, solid media were prepared with $2 \mathrm{~g} / \mathrm{L}$ carboxymethyl cellulose, $2 \%$ bacteriological agar, and a salt solution containing $(\mathrm{g} / \mathrm{L})$ : $\mathrm{NaNO}_{3}(2), \mathrm{K}_{2} \mathrm{HPO}_{4}(1), \mathrm{MgSO}_{4}-7 \mathrm{H}_{2} \mathrm{O}(0.5)$, and $\mathrm{KCl}(0.5)$. The medium was inoculated with the isolated strains and incubated at $28 \pm 1{ }^{\circ} \mathrm{C}$. After the incubation time, in the exponential growth phase of each fungus, $10 \mathrm{~mL}$ of $0.8 \%$ Lugol's iodine was added as a developer until the agar surface was covered, allowed to stand for $5 \mathrm{~min}$ and the Lugol's iodine was redrained, then the mycelial growth and the halo of enzymatic activity by the change in coloration of the medium were measured by images analyzed in ImageJ software using a vernier as a scale [23-26].

\subsection{Xylanase Activity}

For semi-quantitative test of xylanase activity, solid media were prepared with $2 \mathrm{~g} / \mathrm{L}$ birch xylan, $2 \%$ bacteriological agar, and a salt solution containing $(\mathrm{g} / \mathrm{L}): \mathrm{NaNO}_{3}(2)$, $\mathrm{K}_{2} \mathrm{HPO}_{4}(1), \mathrm{MgSO}_{4}-7 \mathrm{H}_{2} \mathrm{O}(0.5)$, and $\mathrm{KCl}(0.5)$. The medium was inoculated with the 
isolated fungi and incubated at $28 \pm 1{ }^{\circ} \mathrm{C}$. After the incubation time, in the exponential growth phase of each fungus, $10 \mathrm{~mL}$ of $0.8 \%$ Lugol's iodine was added as a developer until the agar surface was covered, allowed to stand for $5 \mathrm{~min}$ and the Lugol's iodine was removed, then xylanase activity was determined by measuring the diameter of the mycelial growth and hydrolysis halo of enzyme activity by images analyzed in ImageJ software using a vernier as a scale $[23,26]$.

\subsection{Manganese Peroxidase Activity}

For the semi-quantitative manganese peroxidase activity, solid media were prepared with PDA $39 \mathrm{~g} / \mathrm{L}$ and phenol red $0.5 \mathrm{~g} / \mathrm{L}$ as an oxidative indicator, since the oxidation of the latter by the action of the enzyme produces a discoloration reaction from red to orange. The medium was inoculated with the isolated fungi and incubated at $28 \pm 1{ }^{\circ} \mathrm{C}$. After the incubation time, in the exponential growth phase of each fungus, the mycelial growth and enzyme activity halo (color change of the medium due to the oxidation of phenol red) were measured employing images analyzed in ImageJ software using a vernier as a scale $[21,26,27]$.

The following formula was used to measure the enzyme potency index of cellulase, xylanase, and manganese peroxidase activities:

$$
\mathrm{PI}=\frac{\mathrm{HA}}{\mathrm{HM}}
$$

$\mathrm{PI}=$ enzyme potency index; $\mathrm{HA}=$ halo diameter of the enzyme activity $; \mathrm{HM}=$ halo diameter of fungal mycelium.

\subsection{Lignin Peroxidase Activity}

The medium in which the fungi had the highest growth from which the enzyme extract for the liquid reactions was obtained was inoculated with the isolates and incubated at $28 \pm 1{ }^{\circ} \mathrm{C}$. After the incubation time, during the exponential growth phase of each fungus, the lignin peroxidase enzymatic activity was determined, using ABTS as an oxidizing agent that produces a color change from colorless to blue-green. Liquid reactions with a total volume of $300 \mu \mathrm{L}$ were prepared in triplicate. Each reaction mixture contained $171 \mu \mathrm{L}$ of $100 \mathrm{mM}$ acetate buffer $\mathrm{pH} 3,43 \mu \mathrm{L}$ of $10 \mathrm{mM}$ ABTS as an oxidizing agent, $43 \mu \mathrm{L}$ of enzyme extract previously filtered and centrifuged at $8000 \times g$ for $5 \mathrm{~min}$, and $43 \mu \mathrm{L}$ of hydrogen peroxide. The blank reaction contained $214 \mu \mathrm{L}$ of $100 \mathrm{mM}$ acetate buffer $\mathrm{pH}$, $43 \mu \mathrm{L}$ of enzyme extract, and $43 \mu \mathrm{L}$ of hydrogen peroxide. One blank was made for each sample. Once the reaction mixture was prepared, it was incubated at $30^{\circ} \mathrm{C}$ for $1 \mathrm{~h}$ in a Lumistell IEC-42c incubator, after which time the reaction was stopped by placing the samples in the cold, and absorbance readings were immediately taken on a NanoDrop ONE at $420 \mathrm{~nm}[28,29]$.

The lignin peroxidase enzyme activity was calculated with the following formula:

$$
\mathrm{EA}\left(\frac{\mathrm{U}}{\mathrm{L}}\right)=\frac{\mathrm{a} * \mathrm{TV}}{\varepsilon * 1 * \mathrm{EV} * \mathrm{~T}}
$$

$\mathrm{EA}=$ enzymatic activity expressed in units per liter; $\mathrm{U}=$ moles $\mathrm{ABTS}$ oxidized per minute; $\mathrm{a}=$ absorbance at given $\lambda$; TV $=$ total reaction volume; $\varepsilon=$ molar extinction coefficient at that $\lambda\left(36 \mathrm{M}^{-1} \mathrm{~cm}^{-1}\right) ; 1=$ optical path $(1 \mathrm{~cm}) ; \mathrm{EV}=$ enzyme extract volume; $\mathrm{T}=$ time.

One unit of enzyme activity is defined as the amount of enzyme capable of oxidizing $1 \mathrm{~mol}$ of ABTS per minute.

All assays were performed in triplicate.

\subsection{Experimental Design}

To compare the effect of the different culture conditions, a completely random design was used by obtaining four different treatments, where the carbon source was varied, 
and the media used were: $\mathrm{PH}, \mathrm{CH}$, PS and glucose, three repetitions were performed for each treatment.

\subsection{Statistical Analysis}

For statistical analysis, we performed the analysis of the variance (ANOVA) and the test analysis of Tukey $(p<0.05)$. The Statgraphics XVI.II centurion program was used.

\section{Results}

\subsection{Organisms}

From the three sites SJEP, LVEP, and TecNM-ITTG, 33 fungi specimens were collected. Among the specimens collected were brown-rot fungi and white-rot fungi, among other fungi. Of the 33 specimens collected, 20 strains were isolated and propagated in PDA solid culture medium at $28 \pm 1{ }^{\circ} \mathrm{C}$. The collected specimens were deposited in the CHIP Herbarium of the Jardín Botánico Dr. Faustino Miranda, SEMAHN.

The origin trees from which the isolates from SJEP were derived were Pinus ayacahuite, Pinus strobus, Pinus teocote, Pinus montezumae, Pinus oocarpa, Quercus oleoides and Quercus chartacea; from LVEP were Pinus spp. and Quercus spp.; and the trees from which the isolates from Facilities of TecNM-ITTG were derived were Mangifera indica.

\subsection{Identification}

After carrying out the taxonomic and molecular identification, eighteen species were identified that correspond to the taxonomic category shown in Table 1, indicating the site where they were collected and the rot type.

Table 1. Taxonomic category of the identified specimens.

\begin{tabular}{|c|c|c|c|c|c|c|c|}
\hline Phylum & Class & Order & Family & Name & Collection Site & Record & Rot Type \\
\hline \multirow{9}{*}{ Ascomycota } & \multirow{5}{*}{ Dothideomycetes } & Botryosphaeriales & Aplosporellaceae & $\begin{array}{c}\text { Aplosporella } \\
\text { hesperidica } \\
\text { TecNM-ITTG } \\
\text { L30-1-19 }\end{array}$ & LVEP $^{1}$ & $\mathrm{NR}^{4}$ & $\mathrm{BR}^{5}$ \\
\hline & & & Didymellaceae & $\begin{array}{c}\text { Epicoccum sorghinum } \\
\text { TecNM-ITTG } \\
\text { L15B-19 }\end{array}$ & SJEP ${ }^{2}$ & $\mathrm{NR}^{4}$ & $\mathrm{ND}^{6}$ \\
\hline & & Pleosporales & Leptosphaeriaceae & $\begin{array}{c}\text { Leptosphaeria } \\
\text { spegazzinii } \\
\text { TecNM-ITTG } \\
\text { L15A-19 }\end{array}$ & SJEP 2 & $\mathrm{NR}^{4}$ & $\mathrm{ND}^{6}$ \\
\hline & & & Pleosporaceae & $\begin{array}{c}\text { Curvularia spicifera } \\
\text { TecNM-ITTG L2-2-19 }\end{array}$ & SJEP ${ }^{2}$ & $\mathrm{NR}^{4}$ & $\mathrm{ND}^{6}$ \\
\hline & & Valsariales & Valsariaceae & $\begin{array}{l}\text { Myrmaecium } \\
\text { rubricosum } \\
\text { TecNM-ITTG } \\
\text { L1-2-2-19 }\end{array}$ & SJEP ${ }^{2}$ & $\mathrm{NR}^{4}$ & $\mathrm{ND}^{6}$ \\
\hline & \multirow{4}{*}{ Sordariomycetes } & \multirow{4}{*}{ Hypocreales } & \multirow{4}{*}{ Hypocreaceae } & $\begin{array}{c}\text { Trichoderma } \\
\text { citrinoviride } \\
\text { TecNM-ITTG } \\
\text { L33-2-19 }\end{array}$ & LVEP 1 & $\mathrm{NR}^{4}$ & $\mathrm{ND}^{6}$ \\
\hline & & & & $\begin{array}{c}\text { Trichoderma } \\
\text { harzianum } \\
\text { TecNM-ITTG L23-19 }\end{array}$ & LVEP $^{1}$ & $\mathrm{NR}^{4}$ & $\mathrm{ND}^{6}$ \\
\hline & & & & $\begin{array}{c}\text { Trichoderma } \\
\text { longibrachiatum } \\
\text { TecNM-ITTG } \\
\text { L30-2-19 }\end{array}$ & LVEP $^{1}$ & $\mathrm{NR}^{4}$ & $\mathrm{ND}^{6}$ \\
\hline & & & & $\begin{array}{c}\text { Trichoderma reesei } \\
\text { TecNM-ITTG L4-2-19 }\end{array}$ & SJEP ${ }^{2}$ & $\mathrm{NR}^{4}$ & $\mathrm{ND}^{6}$ \\
\hline
\end{tabular}


Table 1. Cont.

\begin{tabular}{|c|c|c|c|c|c|c|c|}
\hline Phylum & Class & Order & Family & Name & Collection Site & Record & Rot Type \\
\hline & & \multirow{2}{*}{ Xylariales } & Hypoxylaceae & $\begin{array}{c}\text { Hypoxylon } \\
\text { griseobrunneum } \\
\text { TecNM-ITTG } \\
\text { L1-2-1-19 }\end{array}$ & SJEP ${ }^{2}$ & $\mathrm{NR}^{4}$ & $\mathrm{ND}^{6}$ \\
\hline & & & Sporocadaceae & $\begin{array}{l}\text { Neopestalotiopsis } \\
\text { macadamiae } \\
\text { TecNM-ITTG } \\
\text { L27-2-19 }\end{array}$ & LVEP $^{1}$ & $\mathrm{NR}^{4}$ & $\mathrm{WR}^{7}$ \\
\hline \multirow{7}{*}{ Basidiomycota } & \multirow{7}{*}{ Agaricomycetes } & Agaricales & Psathyrellaceae & $\begin{array}{c}\text { Coprinellus } \\
\text { disseminatus } \\
\text { TecNM-ITTG L9-1-19 }\end{array}$ & SJEP 2 & - & $\mathrm{WR}^{7}$ \\
\hline & & \multirow{6}{*}{ Polyporales } & \multirow{4}{*}{ Phanerochaetaceae } & $\begin{array}{l}\text { Hyphodermella rosae } \\
\text { TecNM-ITTG L2-1-19 }\end{array}$ & SJEP 2 & $\mathrm{NR}^{4}$ & $\mathrm{ND}^{6}$ \\
\hline & & & & $\begin{array}{l}\text { Phanerochaete australis } \\
\text { TecNM-ITTG L4-1-19 }\end{array}$ & SJEP ${ }^{2}$ & $\mathrm{NR}^{4}$ & $\mathrm{WR}^{7}$ \\
\hline & & & & $\begin{array}{c}\text { Phanerochaete sordida } \\
\text { TecNM-ITTG } \\
\text { L32-1-19 }\end{array}$ & $\operatorname{LVEP}^{1}$ & $\mathrm{NR}^{4}$ & $\mathrm{WR}^{7}$ \\
\hline & & & & $\begin{array}{l}\text { Phlebiopsis flavidoalba } \\
\text { TecNM-ITTG L20-19 }\end{array}$ & $\operatorname{LVEP}^{1}$ & $\mathrm{NR}^{4}$ & $\mathrm{WR}^{7}$ \\
\hline & & & \multirow{2}{*}{ Polyporaceae } & $\begin{array}{l}\text { Trametes cingulata } \\
\text { TecNM-ITTG L13-19 }\end{array}$ & TecNM-ITTG $^{3}$ & $\mathrm{NR}^{4}$ & $\mathrm{WR}^{7}$ \\
\hline & & & & $\begin{array}{l}\text { Trametes sanguinea } \\
\text { TecNM-ITTG L14-19 }\end{array}$ & TecNM-ITTG ${ }^{3}$ & - & $\mathrm{WR}^{7}$ \\
\hline
\end{tabular}

${ }^{1}$ LVEP: “Laguna Verde" Ecotourism Park; ${ }^{2}$ SJEP: "San José" Educational Park; ${ }^{3}$ TecNM-ITTG: National Technological of MexicoTechnological Institute of Tuxtla Gutiérrez; ${ }^{4}$ NR: New Record for the state of Chiapas according to CONABIO data; ${ }^{5}$ BR: brown rot; ${ }^{6}$ ND: not determined; ${ }^{7} \mathrm{WR}$ : white rot.

\subsection{Solid Media Growth}

All species grew on the lignocellulosic media with the agroindustrial substrates as a carbon source; however, the highest growth rate was found on the coffee husk medium (Figure 1).

According to the statistical analysis, strain Trichoderma harzianum TecNM-ITTG L2319 presents a statistically significant difference concerning the others, since it had the highest growth rate in the medium with coffee husk $(30 \mathrm{~mm} / \mathrm{d})$, while strain Curvularia spicifera TecNM-ITTG L2-2-19 (2 mm/d) showed the lowest growth rate, followed by Neopestalotiopsis macadamiae TecNM-ITTG L27-2-19 (2.25 mm/d).

\subsection{Cellulase Activity}

Eighteen isolates were evaluated, and the statistical analysis indicates that strain Phlebiopsis flavidoalba TecNM-ITTG L20-19 presents a statistically significant difference concerning the others, since it had the highest cellulase activity potency index (2.01), while strain Hyphodermella rosae TecNM-ITTG L2-1-19 (0.436) was the one with the lowest cellulase activity PI; on the other hand, six of the strains evaluated (Trichoderma citrinoviride TecNMITTG L33-2-19, Trichoderma harzianum TecNM-ITTG L23-19, Trichoderma longibrachiatum TecNM-ITTG L30-2-19, Trichoderma reesei TecNM-ITTG L4-2-19, Neopestalotiopsis macadamiae TecNM-ITTG L27-2-19 and Phanerochaete australis TecNM-ITTG L4-1-19) did not present cellulase activity (Figure 2). 




Figure 1. Growth rate in media with lignocellulosic material of the 18 isolates; $a, b, c, d$ : homogeneous groups according to statistical analysis.

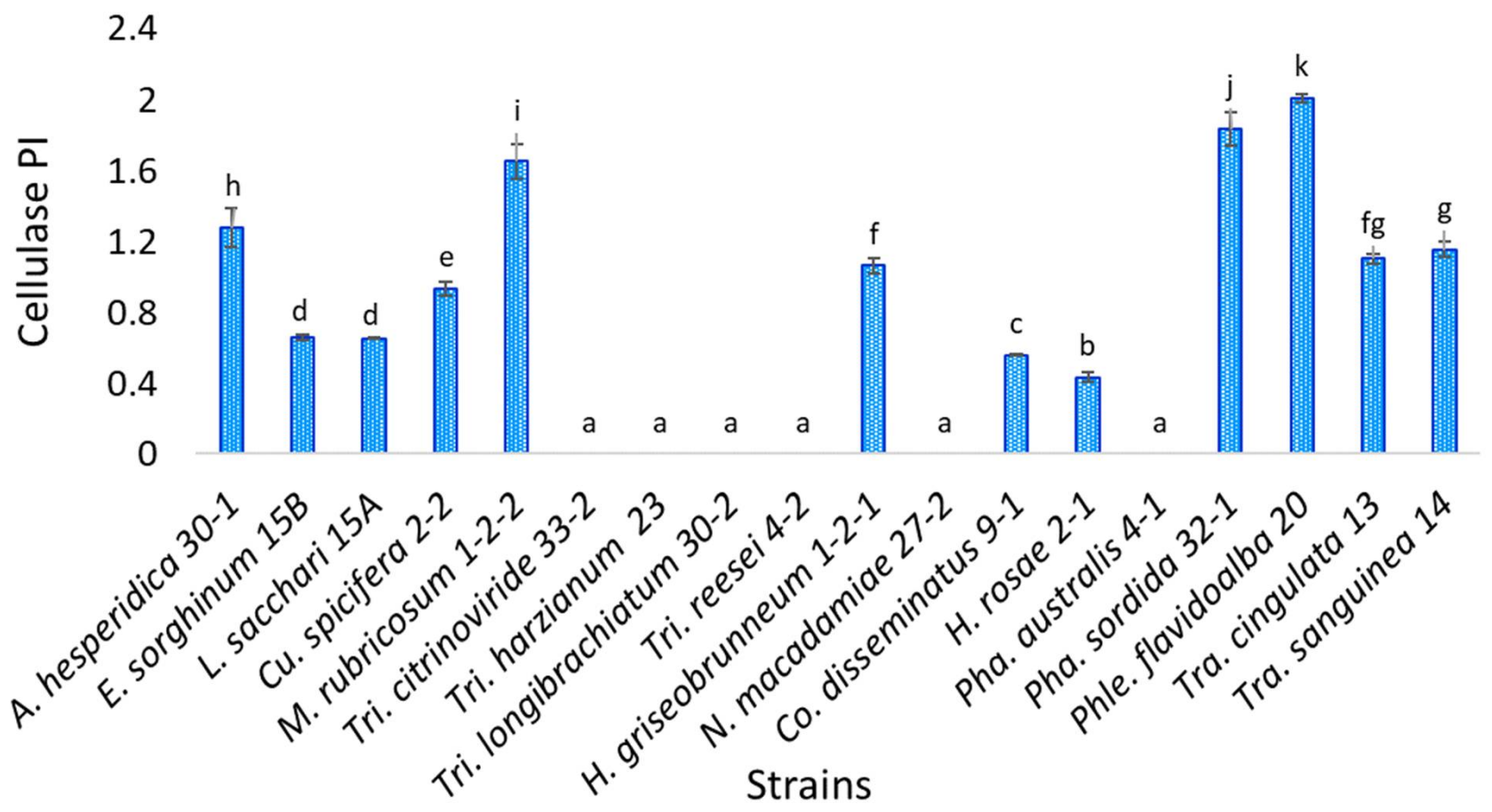

Figure 2. Semi-quantitative cellulase activity of the 18 isolates evaluated; a, b, c, d, e, f, g, h, i, j, k: homogeneous groups according to statistical analysis. 


\subsection{Xylanase Enzyme Activity}

Statistical analysis indicates that of the eighteen isolates evaluated, Phanerochaete sordida TecNM-ITTG L32-1-19 presents a statistically significant difference concerning the others, being the strain with the highest xylanase activity potency index (2.239), while the strain with the lowest potency index was Coprinellus disseminatus TecNM-ITTG L9-1-19 (0.470) (Figure 3). Six of the strains evaluated did not show xylanase activity, the same strains that did not have cellulase activity.

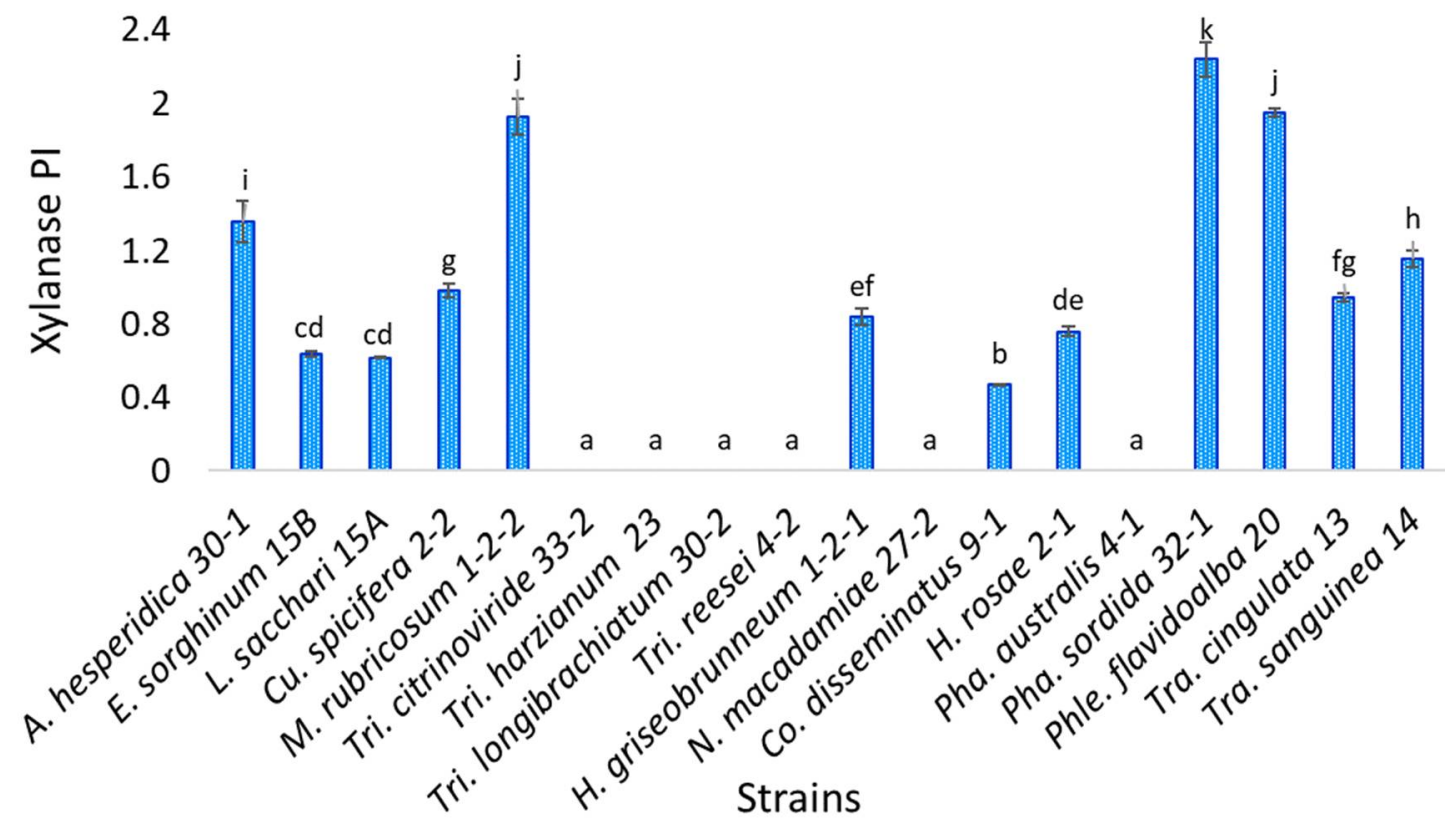

Figure 3. Semi-quantitative xylanase activity of the 18 isolates evaluated; a, b, c, d, e, f, g, h, i, j, k: homogeneous groups according to statistical analysis.

\subsection{Manganese Peroxidase Activity}

Eighteen isolates were evaluated, and statistical analysis indicates that strain Phlebiopsis flavidoalba TecNM-ITTG L20-19 presents a statistically significant difference to the others, being the strain with the highest potency index of manganese peroxidase activity (1.673), which is a white-rot fungus, while the strain with the lowest potency index was Trichoderma citrinoviride TecNM-ITTG L33-2-19 (0.664) (Figure 4). Fifteen percent of the strains evaluated showed no manganese peroxidase activity (Trichoderma reesei TecNM-ITTG L4-2-19, Phanerochaete australis TecNM-ITTG L4-1-19 and Epicoccum sorghinum TecNM-ITTG L15B-19).

\subsection{Lignin Peroxidase Activity}

The lignin peroxidase enzyme was quantified in the eighteen isolates evaluated from liquid media with coffee husk, in which the fungi had the highest growth. According to the statistical analysis, the strain Trametes sanguinea TecNM-ITTG L14-19 presents a statistically significant difference concerning the others, which had the highest amount of lignin peroxidase enzyme $(7115.226 \mathrm{U} / \mathrm{L})$, which is a white-rot fungus, while the strain with the lowest amount of enzyme was Trichoderma longibrachiatum TecNM-ITTG L30-2-19 (540.123) U/L (Figure 5). 


\section{4}

2

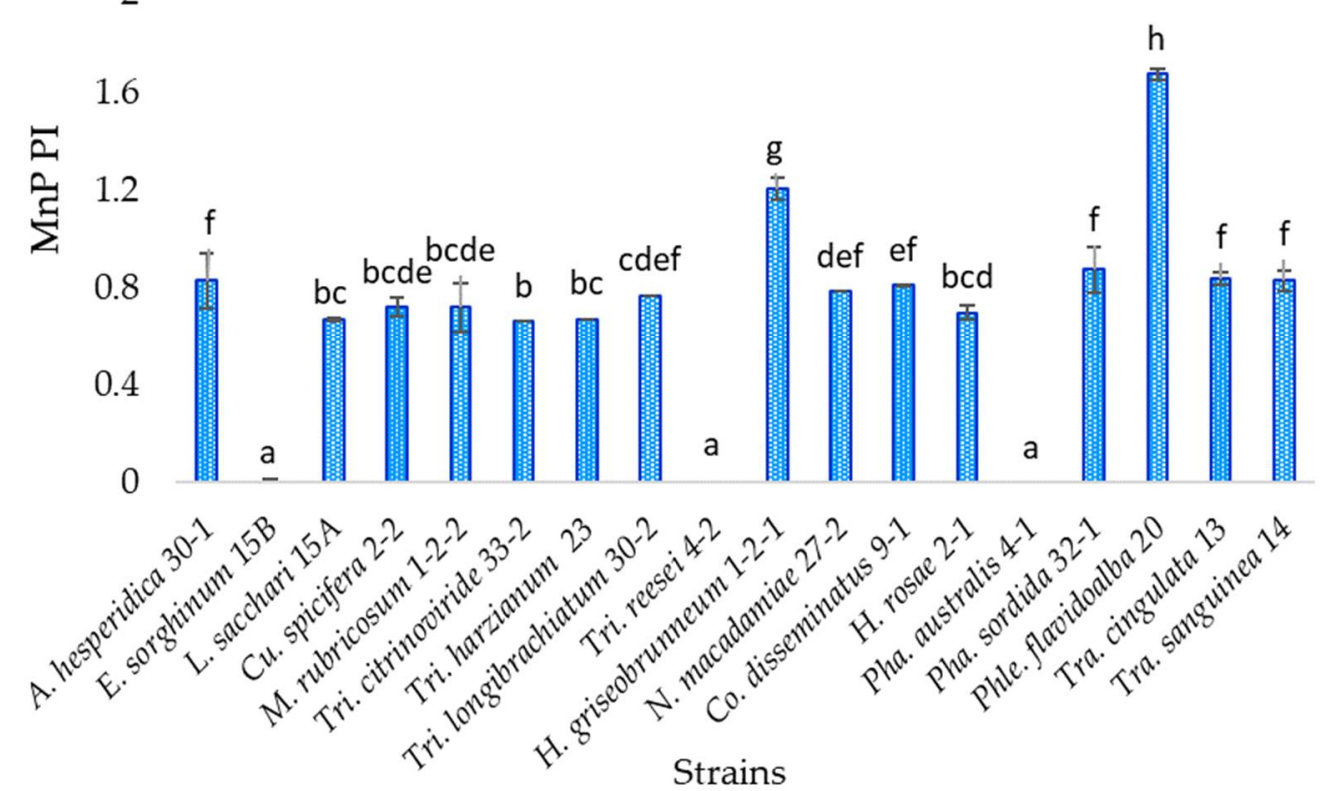

Figure 4. Semi-quantitative manganese peroxidase activity of the 18 isolates evaluated; a, b, c, d, e, f, g, h: homogeneous groups according to statistical analysis.

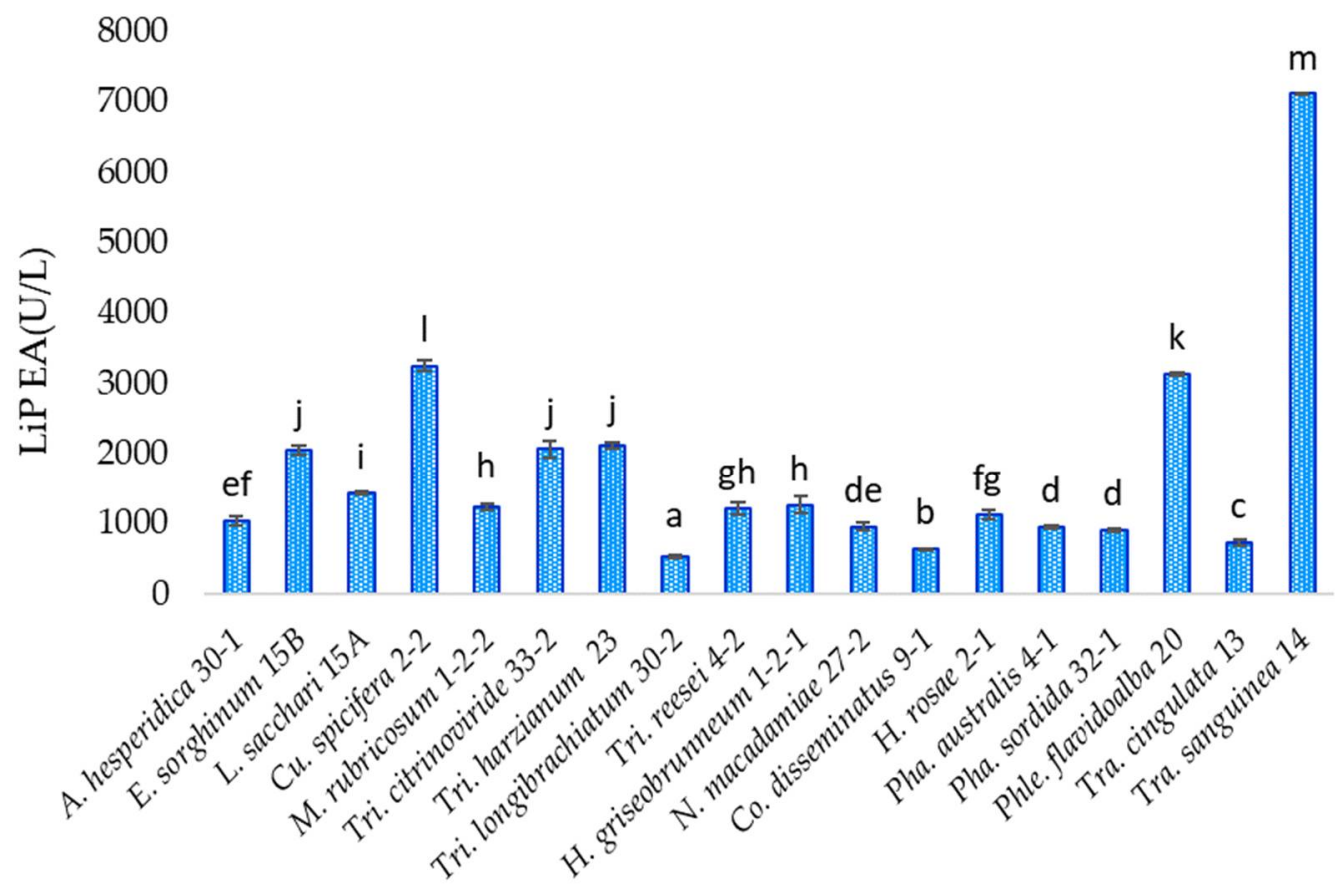

\section{Strains}

Figure 5. Quantitative manganese peroxidase activity of the 18 isolates evaluated; a, b, c, d, e, f, g, h, i, j, k, l, m: homogeneous groups according to statistical analysis.

\section{Discussion}

Of the total number of strains identified, $89 \%$ are new records for the state of Chiapas, according to information from the catalog of the National Commission for the Knowledge and Use of Biodiversity (CONABIO by its Spanish acronym) and various publications and 
research carried out. The total number of new records indicates the importance of complete mycological studies for the state of Chiapas.

Wood-rot fungi are primarily responsible for the decomposition of lignocellulose, the most recalcitrant molecules in wood, and thus are critical in nutrient and carbon cycling in forest ecosystems. Wood-decomposing agaricomycetes produce three basic types of decomposition based on complex enzyme systems: white, brown, and soft rot [30]. Of the species identified, seven belong to the class of agaricomycetes, of which six are from the order of polypores and one from the order of Agaricales.

The common characteristic of white-rot fungi is the extensive degradation of lignin resulting in a whitish appearance of rotted wood. White-rot fungi comprise numerous fungi, mostly Basidiomycota belonging to the orders Polyporales and Agaricales. During wood decay, degradation occurs at a great distance from the hyphae by the diffusion of enzymes; the mechanism of action of the enzymes involved and the patterns of wood decay have been extensively studied since the late 1970s [31].

One characteristic of some Agaricomycetes is wood decay, especially white rot. Although several microorganisms degrade the polysaccharides (cellulose and hemicellulose) contained in woody biomass, the brown-rot and white-rot Agaricomycetes are considered key players in wood decay in nature. Brown-rot fungi depolymerize crystalline cellulose by cellulolytic enzymes and non-enzymatic mechanisms, and white-rot fungi are the species that almost exclusively biodegrade wood lignin in nature.

Of the wood decay fungi identified, one belongs to the order Agaricales, basidiomycetes fungi reported for the treatment of aromatic compounds such as nonylphenol, where the fungal degradation capacity is related to the secretion of ligninolytic enzymes such as laccase and $\mathrm{MnP}$ [32]. In turn, six species of the order Polyporales were identified (Hyphodermella rosae TecNM-ITTG L2-1-19, Phanerochaete australis TecNM-ITTG L4-1-19, Phanerochaete sordida TecNM-ITTG L32-1-19, Phlebiopsis flavidoalba TecNM-ITTG L20-19, Trametes cingulata TecNM-ITTG L13-19 and Trametes sanguinea TecNM-ITTG L14-19), species of fungi belonging to the order Polyporales, and they excrete high levels of the enzyme laccase and MnP [33]. The Polyporaceae family is one of the families that has numerous wood-degrading fungal species that have been thoroughly investigated for the production of lignin-modifying enzymes and their potential for industrial applications.

Thirty-nine classes of fungi found in waste degradation were reported, among which the Sordariomycetes class stands out, as species of this class were identified as the main cellulase producers. In addition to possessing genes that degrade lignocellulose, Sordariomycetes are efficient lignocellulose decomposers that can produce considerable amounts of lignocellulosic enzymes [34]. Among the fungi studied, six were found to belong to the class of Sordariomycetes within the order Hypocreales and Xylariales with four and two species of each, respectively. However, it is important to note that the order Xylariales have been reported as pathogenic fungi [35], belonging to the class Sordariomycetes, while other endophytic fungi also from the order Xylariales have been reported with antagonistic activity against phytopathogenic fungi [36].

Five fungi of the class Dothideomycetes, of the order Botryosphaeriales, Pleosporales, and Valsariales, were identified. Dothideomycetes are one of the most important classes of ascomycete fungi and comprise an incredible diversity of natural habitats [37].

Species of the genera Coprinus, Panaeolus, Schizophyllum, Psilocybe, Trametes, Polyporus and Pycnoporus have been reported as indicators of anthropogenic disturbance, and together with Ganoderma and Rigidoporus are typical species of tropical or humid subtropical forests, which is an ecological indication that the LVEP zone is a transitional area or an area with a certain degree of disturbance, since they tend to displace tropical forest species and to fruit in places used by humans as cultivated areas. While the families Agaricaceae, Entolomataceae, Tricholomataceae and Lepiotaceae can be considered as indicators of disturbance because they require certain very particular conditions for their development, it can be pointed out that some species of these families are located in areas disturbed by agriculture and/or cattle ranching, which were identified in this site, where a mixture of 
different forms of land use was observed, affecting mycological diversity, as in the case of the Coapilla forest. The Agaricaceae and Polyporaceae families are the most abundant in tropical zones and were identified within the TecNM-ITTG facilities.

The tropical species that were identified from the collection made in the LVEP, that have also been found in pine-oak forests, perhaps it is due it is a transition zone between different types of vegetation, or the thermophilic influence of the Pacific Ocean slope originated by its geographic position. Besides, fungal distribution is closely related to the ability to develop under different abiotic conditions (temperature, humidity, $\mathrm{pH}$ ), mechanisms of dormancy, and spore dispersal, and taking into account that the macromycetes' mycelia can range from millimeters to entire landscapes, it is difficult to determine the area occupied by each individual, which makes it impossible to measure the different parameters of biodiversity [38].

Fungi of the genus Trametes have been reported as medicinal mushrooms [38]. Identified species of these families were collected from the SJEP and TecNM-ITTG.

The most abundant fungi growing on organic matter reported for SJEP belong to the Polyporaceae family. Meanwhile, saprophytic and mycorrhizal fungi are important organisms for the ecological balance of the forest because they decompose organic matter and degrade cellulose, hemicellulose, and lignin in the ecosystems, and contribute to the formation of humus and the soil remineralization process. Agaricales and Polyporales fungi can adapt to changing conditions of temperature, humidity, and rainfall through various dispersal strategies adapted to rain and wind, indicating that they are more suitable for environments with moderate disturbance or disturbance [10], and of those collected at this site, three strains identified belong to the order of Agaricales and Polyporales.

The 18 isolates evaluated grew in the media with lignocellulosic material containing lignin among other compounds, and pine sawdust represents a reference since the fungi were collected from pine tree trunks; however, the medium with coffee husk propitiated that the growth rate in 16 of the 18 isolates evaluated was higher than in the medium with glucose (control), which is an easily accessible carbon source. This shows that the isolates are capable of taking as a carbon source the compounds contained in the medium, such as cellulose, pentoses, hexoses, melanoidin, and complex compounds that contain aromatic rings in their structure, such as chlorogenic acid, caffeine, lignin, caffeic acid, phenolic compounds, etc., to transform them and use them as a source of energy.

The strain Trichoderma harzianum TecNM-ITTG L23-19 presented the highest growth rate in the medium with coffee husk and expressed the enzymes manganese peroxidase and lignin peroxidase, which are involved in degradation reactions of complex compounds, and by not expressing the enzymes xylanase and cellulase hydrolases, this indicates evidence of a probable more specific metabolism to degrade more complex molecules such as aromatic compounds present in the medium.

The strains Curvularia spicifera TecNM-ITTG L2-2-19 and Coprinellus disseminatus TecNM-ITTG L9-1-19 were the only ones that had a higher growth rate in the medium with glucose, that is, the control medium, than in the medium with coffee husk, in addition to expressing the enzymatic activities hydrolase xylanase and cellulase, which suggests a metabolism oriented to the degradation of less complex compounds, thus having more affinity for simpler carbon sources such as glucose.

These are agroindustrial residues that are produced in large quantities in the state of Chiapas, are low cost, and are of biotechnological interest. Coffee husks represent 5 to $12 \%$ of the coffee fruit [39], with Chiapas being the main coffee producer with $41 \%$ at the national level [40] of about 860 thousand tons of coffee [41]. Chiapas is the main producer of African palm in the country, with $57.3 \%$ [42].

Oxidase enzymes such as MnP and LiP are found in Ascomycetes and Basidiomycetes fungi; however, not all of them produce all the enzymes at the same time, or the same quantity of them, and diverse fungi produce different combinations of enzymes, even within the same genus, as occurred among the strains Trichoderma citrinoviride TecNM-ITTG L33-2-19, Trichoderma harzianum TecNM-ITTG L23-19, Trichoderma longibrachiatum TecNM- 
ITTG L30-2-19 and Trichoderma reesei TecNM-ITTG L4-2-19, where one of them did not present MnP activity (Figure 4); or between Trametes cingulata TecNM-ITTG L13-19 and Trametes sanguinea TecNM-ITTG L14-19, also of the same genus, which had very different LiP production (Figure 5) with 741.770 and $7115.226 \mathrm{U} / \mathrm{L}$, respectively, in addition to having growth rates between 2 and $7 \mathrm{~mm} / \mathrm{d}$, indicating that the strain growth rate is not directly related to enzyme production and therefore does not determine its metabolism and degradation mechanisms.

The Epicoccum sorghinum TecNM-ITTG L15B-19 strain showed the production of hydrolase enzymes: cellulase using carboxymethyl cellulose as a substrate and xylanase using birch xylan as a substrate to induce the production of enzymes aimed at the degradation of hardwoods. On the other hand, the strains Trichoderma citrinoviride TecNM-ITTG L33-2-19, Trichoderma harzianum TecNM-ITTG L23-19 and Trichoderma longibrachiatum TecNM-ITTG L30-2-19 did not present hydrolase activities: cellulase and xylanase while they had oxidase activities: manganese peroxidase and lignin peroxidase.

The different combinations of ligninolytic enzyme development indicate different abilities of fungi to degrade media containing lignin or other aromatic compounds, which may be related to their biodegradation strategies [43].

\section{Conclusions}

The evaluated fungi that were collected in the state of Chiapas produced hydrolase and oxidase enzymes. The presence of hydrolase (cellulase and xylanase) and oxidase (MnP and LiP) activities in fungi allowed us to classify them into brown-rot fungi, such as the case of the Aplosporella hesperidica TecNM-ITTG L30-1-19 strain, and white-rot fungi such as the Trametes sanguinea strain TecNM-ITTG L14-19 and the Phlebiopsis flavidoalba strain TecNM-ITTG L20-19, representing thirty-nine percent of the isolated strains evaluated.

The fungi growth in PH, CH and PS allowed us to identify a complex metabolism that involves hydrolase and oxidase enzymes.

The species of fungi that were collected in the state of Chiapas are diverse and belong to the ascomycotic and basidiomycotic phylum, which have equivalent enzymatic activities in addition to not being related to the species.

The fact that eighty-nine percent of the species identified represent new records for the state of Chiapas, according to $\mathrm{CONABIO}$ data, indicates the importance and relevance of carrying out complete mycological studies for the State of Chiapas, since thanks to the region in which it is located, it has multiple ecosystems that show evidence of the exorbitant prevailing biodiversity.

The present work opens new perspectives for future research regarding the study of lignocellulolytic enzyme-producing fungi and their biotechnological applications.

Author Contributions: Conceptualization, S.E.-S., P.E.Á.-G. and L.D.S.-C.; methodology, P.E.Á.-G. and R.M.-G.; software, L.D.S.-C.; investigation, S.E.-S., P.E.Á.-G. and L.D.S.-C.; writing-original draft preparation, L.D.S.-C.; writing-review and editing, S.E.-S., P.E.Á.-G., R.M.-G., J.J.V.-M., L.D.S.-C. and S.E.-P.; supervision, S.E.-S. and J.J.V.-M. All authors have read and agreed to the published version of the manuscript.

Funding: This research was funded by National Technological of Mexico, scientific research project titled "Evaluation of the ability of lignocellulolytic fungi to use aromatic compounds as a carbon source". This work was supported by the National Council for Science and Technology (CONACYT by its Spanish acronym), with a doctoral fellowship from the program $\mathrm{PhD}$ in Food Sciences and Biotechnology with doctoral fellow number 405033.

Institutional Review Board Statement: Not applicable.

Informed Consent Statement: Not applicable.

Data Availability Statement: Not applicable.

Acknowledgments: To the National Council for Science and Technology and the laboratories of the National Technological of Mexico-Technological Institute of Tuxtla Gutiérrez. 
Conflicts of Interest: The authors declare no conflict of interest. The funders had no role in the design of the study; in the collection, analyses, or interpretation of data; in the writing of the manuscript, or in the decision to publish the results.

\section{References}

1. Iram, A.; Cekmecelioglu, D.; Demirci, A. Ideal Feedstock and Fermentation Process Improvements for the Production of Lignocellulolytic Enzymes. Processes 2021, 9, 38. [CrossRef]

2. Montoya, S.; Patiño, A.; Sánchez, Ó.J. Production of Lignocellulolytic Enzymes and Biomass of Trametes versicolor from AgroIndustrial Residues in a Novel Fixed-Bed Bioreactor with Natural Convection and Forced Aeration at Pilot Scale. Processes 2021, 9, 397. [CrossRef]

3. Dao, A.T.N.; Smits, M.; Dang, H.T.C.; Brouwer, A.; de Boer, T.E. Elucidating fungal Rigidoporus species FMD21 lignin-modifying enzyme genes and 2,3,7,8-tetrachlorodibenzo-p-dioxin degradation by laccase isozymes. Enzym. Microb. Technol. 2021, 147, 109800. [CrossRef]

4. De Gonzalo, G.; Colpa, D.I.; Habib, M.H.M.; Fraaije, M.W. Bacterial enzymes involved in lignin degradation. J. Biotechnol. 2016, 23, 110-119. [CrossRef]

5. Schmidt, O. Wood and Tree Fungi. Biology, Damage, Protection, and Use, 1st ed.; Springer: Berlin/Heidelberg, Germany, 2006; pp. 134-146.

6. Papinutti, L. Hongos causantes de pudrición blanca: La utilización de sus enzimas ligninolíticas para el desarrollo de tecnologías de biorremediación. Cienc. Nat. 2011, 24, 40-42.

7. Alshammari, N.; Ameen, F.; AlKahtani, M.D.F.; Stephenson, S. Characterizing the Assemblage of Wood-Decay Fungi in the Forests of Northwest Arkansas. J. Fungi 2021, 7, 309. [CrossRef] [PubMed]

8. Tanruean, K.; Penkhrue, W.; Kumla, J.; Suwannarach, N.; Lumyong, S. Valorization of LignocellulosicWastes to Produce Phytase and Cellulolytic Enzymes from a Thermophilic Fungus, Thermoascus aurantiacus SL16W, under Semi-Solid State Fermentation. J. Fungi 2021, 7, 286. [CrossRef]

9. Secretaría del Medio Ambiente e Historia Natural (SEMAHN). Available online: http://www.semahn.chiapas.gob.mx/portal/ san_jose/conocenos (accessed on 21 January 2019).

10. Chanona-Gómez, F.; Alvarez-Gutiérrez, P.E.; Pérez-Luna, Y.C. Macromycetes of the San José educational park, municipality of Zinacantan, Chiapas, Mexico. Acta Univ. 2019, 29, 1-13. [CrossRef]

11. Instituto Nacional para el Federalismo y el Desarrollo Municipal. Enciclopedia de los Municipios y Delegaciones de México Available online: http://www.inafed.gob.mx/work/enciclopedia/EMM07chiapas/municipios/07018a.html (accessed on 4 April 2019).

12. Instituto Nacional para el Federalismo y el Desarrollo Municipal. Enciclopedia de los Municipios y Delegaciones de México. Available online: http://www.inafed.gob.mx/work/enciclopedia/EMM07chiapas/municipios/07101a.html (accessed on 4 April 2019).

13. Guzmán, G. Identificación de los Hongos Comestibles, Venenosos, Alucinantes y Destructores de la Madera, 1st ed.; Limusa: Monterrey, México, 1977; pp. 435-436.

14. Ryvarden, L.; Gilbertson, R.L. European Polyporus; Grolands Grafiske Als: Oslo, Norway, 1983; pp. $149-170$.

15. Ryvarden, L.; Gilbertson, R.L. North American Polyporus Vol. I; Grolands Grafiske Als: Oslo, Norway, 1986 ; pp. $1-437$.

16. Ryvarden, L.; Gilbertson, R.L. North American Polyporus Vol. II; Grolands Grafiske Als: Oslo, Norway, 1987 ; pp. $438-885$.

17. Ryvarden, L. Chapter 9: Tropical polypores. In Aspects of Tropical Mycology; Simposium of the British Mycological Society, held at the University of Liverpool, Reino Unido; Cambridge University Press: Cambridge, UK, 1991; pp. 149-170.

18. White, T.J.; Bruns, T.; Lee, S.; Taylor, J.W. Amplification and Direct Sequencing of Fungal Ribosomal RNA Genes for Phylogenetics. In PCR Protocols: A Guide to Methods and Applications, 1st ed.; Innis, M.A., Gelgard, D.H., Sninsky, J.J., White, T.J., Eds.; Academic Press: New York, NY, USA, 1990; pp. 315-322.

19. Morgulis, A.; Coulouris, G.; Raytselis, Y.; Madden, T.L.; Agarwala, R.; Schäffer, A.A. Database Indexing for Production MegaBLAST Searches. Bioinformatics 2008, 24, 1757-1764. [CrossRef] [PubMed]

20. Morales, P.; Cáceres, M.; Scott, F.; Díaz-Robles, L.; Aroca, G.; Vergara-Fernández, A. Biodegradation of benzo[ $\alpha]$ pyrene, toluene, and formaldehyde from the gas phase by a consortium of Rhodococcus erythropolis and Fusarium solani. Appl. Microbiol. Biotechnol. 2017, 101, 6765-6777. [CrossRef]

21. Gómez, G. Caracterización Bioquímica y molecular de Macromicetos Degradadores de Madera del Rancho El Arco, Cintalapa, Chiapas. Bachelor's Thesis, Instituto De Ciencias Biológicas, Universidad De Ciencias y Artes De Chiapas, Tuxtla Gutiérrez, Chiapas, México, October 2015.

22. Rojas-Solís, D.; Santoyo, G. Data on the effect of Pseudomonas stutzeri E25 and Stenotrophomonas maltophilia CR71 culture supernatants on the mycelial growth of Botrytiscinerea. Data Brief 2018, 17, 234-236. [CrossRef] [PubMed]

23. Amadi, O.C.; Egong, E.J.; Nwagu, T.N.; Okpala, G.; Onwosi, C.O.; Chukwu, G.C.; Okolo, B.N.; Agu, R.C.; Moneke, A.N. Process optimization for simultaneous production of cellulase, xylanase and ligninase by Saccharomyces cerevisiae SCPW 17 under solid state fermentation using Box-Behnken experimental design. Heliyon 2020, 6, e04566. [CrossRef] [PubMed]

24. Orwa, P.; Mugambi, G.; Wekesa, V.; Mwirichia, R. Isolation of haloalkaliphilic fungi from Lake Magadi in Kenya. Heliyon 2020, 6, e02823. [CrossRef] [PubMed] 
25. Silva, M.C.S.; Polonio, J.C.; Quecine, M.C.; Almeida, T.T.; Bogas, A.C.; Pamphile, J.A.; Pereira, J.O.; Astolfi-Filho, S.; Azevedo, J.L. Endophytic cultivable bacterial community obtained from the Paullinia cupana seed in Amazonas and Bahia regions and its antagonistic effects against Colletotrichum gloeosporioides. Microb. Pathog. 2016, 98, 16-22. [CrossRef] [PubMed]

26. Maldonado-Bustamante, S.R.; Mondaca-Fernández, I.; Caro-Reyes, R.B.; Gámez-Gutiérrez, L.A.; De los Santos-Villalobos, S.; Meza-Montenegro, M.M.; Balderas-Cortés, J.J. Selección de cepas productoras de enzimas ligninolíticas nativas del Valle del Yaqui. Nova Sci. 2017, 9, 24-36. [CrossRef]

27. Muñoz, L.D. Evaluación de Enzimas Degradadoras de Lignina Producidas por Aislamientos Fúngicos de Cultivos de Arroz. Bachelor's Thesis, Facultad de ciencias, Pontificia Universidad Javeriana, Bogotá, Colombia, December 2012.

28. Páez, M. Determinación de la Actividad Enzimática de Lacasas y Lignina Peroxidasas de Hongos Degradadores de Colorantes Seleccionados para el Tratamiento de Aguas Residuales de la Industria Textil. Bachelor's Thesis, Departamento de Ciencias de la Vida, Escuela Politécnica del Ejército, Sangolquí, Ecuador, 20 April 2012.

29. Córdoba, R.; Cultid, G. Estudio Comparativo de la Actividad Enzimática de Lacasa (Lac), Lignina Peroxidasa (LiP) y Manganeso Peroxidasa (MnP) de "Pleurotus ostreatus" Cultivado en Residuos Lignocelulósicos de Raquis de Palma de Aceite, Bagazo de Fique y Pulpa de Café. Bachelor's Thesis, Facultad de Ciencias exactas y naturales, Universidad de Nariño, San Juan de Pasto, Colombia, January 2015.

30. Martínez, S.; Nakasone, K.K.; Bettucci, L. Diversity of wood-inhabiting Agaricomycotina on wood of different size classes in riparian forests of Uruguay. Mycoscience 2019, 60, 156-164. [CrossRef]

31. Arora, A.; Nandal, P.; Singh, J.; Verma, M.L. Nanobiotechnological advancements in lignocellulosic biomass pretreatment. Mater. Sci. Energy Technol. 2020, 3, 308-318. [CrossRef]

32. Mallerman, J.; Itria, R.; Babay, P.; Saparrat, M.; Levin, L. Biodegradation of nonylphenol polyethoxylates by litter-basidiomycetous fungi. J. Environ. Chem. Eng. 2019, 7, 103316. [CrossRef]

33. Dao, A.T.N.; Vonck, J.; Janssens, T.K.S.; Dang, H.T.C.; Brouwer, A.; de Boer, T.E. Screening white-rot fungi for bioremediation potential of 2,3,7,8-tetrachlorodibenzo-p-dioxin. Ind. Crop. Prod. 2019, 128, 153-161. [CrossRef]

34. Wang, W.; Zhang, Q.; Sun, X.; Chen, D.; Insam, H.; Koide, R.T.; Zhang, S. Effects of mixed-species litter on bacterial and fungal lignocellulose degradation functions during litter decomposition. Soil Biol. Biochem. 2020, 141, 107690. [CrossRef]

35. Fan, K.; Delgado-Baquerizo, M.; Guo, X.; Wang, D.; Zhu, Y.G.; Chu, H. Microbial resistance promotes plant production in a four-decade nutrient fertilization experiment. Soil Biol. Biochem. 2020, 141, 107679. [CrossRef]

36. Segaran, G.; Sathiavelu, M. Fungal endophytes: A potent biocontrol agent and a bioactive metabolites reservoir. Biocatal. Agric. Biotechnol. 2019, 21, 101284. [CrossRef]

37. Haridas, S.; Albert, R.; Binder, M.; Bloem, J.; LaButti, K.; Salamov, A.; Andreopoulos, B.; Baker, S.E.; Barry, K.; Bills, G.; et al. 101 Dothideomycetes genomes: A test case for predicting lifestyles and emergence of pathogens. Stud. Mycol. 2020, 96, 141-153. [CrossRef] [PubMed]

38. Serrano-Heleria, C.G. Macromicetos de "Laguna Verde”, Municipio de Coapilla, Chiapas. Bachelor's Thesis, Instituto de Ciencias Biológicas, Universidad de Ciencias y Artes de Chiapas, Tuxtla Gutiérrez, Chiapas, México, 2 February 2018.

39. García, A. Evaluación de la Cascarilla de Café para Utilizarse Como Sustrato en Cultivo Sin Suelo de Hortalizas. Master's Thesis, Instituto Politécnico Nacional, Oaxaca, México, January 2008. Available online: https://tesis.ipn.mx/jspui/handle/123456789/ 152 (accessed on 19 February 2021).

40. Servicio de Información Agroalimentaria y Pesquera (SIAP). Café: Datos Preliminares a 2017 Indican una Producción Nacional de 839 Mil Toneladas. Available online: https:/ / www.gob.mx/siap/articulos/cafe-datos-preliminares-a-2017-indican-unaproduccion-nacional-de-839-mil-toneladas (accessed on 19 February 2021).

41. Secretaría de Agricultura y Desarrollo Rural. El Café Una Producción en Manos Sabias. Available online: https://www.gob.mx/ agricultura/articulos / el-cafe-una-produccion-en-manos-sabias?idiom=es (accessed on 19 February 2021).

42. Servicio de Información Agroalimentaria y Pesquera (SIAP). Palma Africana o de Aceite en México: Cultivo Tropical Aceitero. Available online: https: / www.gob.mx/siap/articulos/palma-africana-o-de-aceite-en-mexico-cultivo-tropical-aceitero?idiom= es (accessed on 19 February 2021).

43. Al-Zaban, M.I.; AlHarbi, M.A.; Mahmoud, M.A. Hydrocarbon biodegradation and transcriptome responses of cellulase, peroxidase, and laccase encoding genes inhabiting rhizospheric fungal isolates. Saudi J. Biol. Sci. 2021, 28, 2083-2090. [CrossRef] 